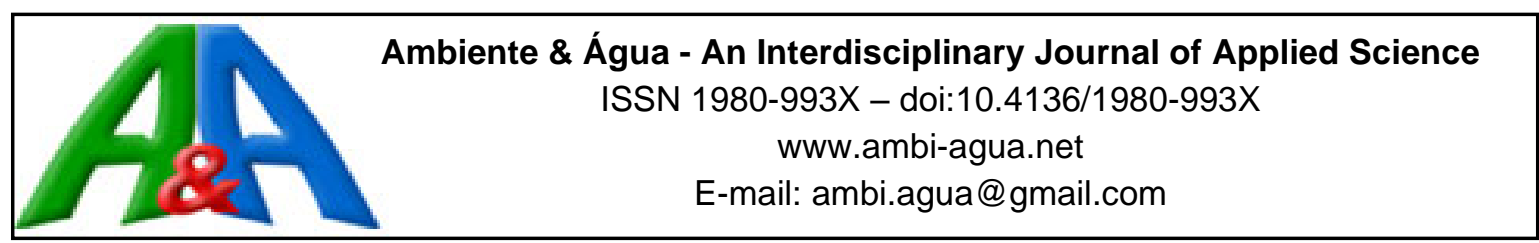

\title{
The pesticide applicator profile of São José dos Quatro Marcos - MT
}

\author{
doi:10.4136/ambi-agua.2306 \\ Received: 15 Nov. 2019; Accepted: 19 Dec. 2019 \\ Cláudia Villar dos Santos*; Adriana Mascarette Labinas
}

Programa de Pós-graduação em Ciências Ambientais. Universidade de Taubaté (UNITAU), Rua Visconde do Rio Branco, n 210, CEP: 12020-240, Taubaté, SP, Brazil. E-mail: alabinas@uol.com.br

*Corresponding author. E-mail: villar_qm@hotmail.com

\begin{abstract}
In order for the correct final destination of empty pesticide packaging to occur, the participation of the entire production chain, from the manufacturer, shopkeeper to the users (farmers) must be involved. The legislation is very clear and demanding about correct disposal, but control is sometimes flawed, and incorrect disposal occurs which can poison humans and contaminate water bodies and animals. This is likely due to lack of information and training or even insufficient information. Thus, the objective of this research was to diagnose the behavior of a group of farmers from São José dos Quatro Marcos (MT) regarding the correct disposal of empty pesticide packages, through semi-structured interviews and bibliographic research. We conclude that the educational level of farmers could be one of the major factors interfering with their knowledge of pesticides, causing this lack of prior knowledge to result in actions understood as being commonplace when working with pesticides.
\end{abstract}

Keywords: environmental psychology, environmental sciences, legislation, pesticides.

\section{O perfil do aplicador de agrotóxicos de São José dos Quatro Marcos - MT}

\section{RESUMO}

Para que ocorra a correta destinação final das embalagens vazias de agrotóxicos é necessário a participação de toda a cadeia produtiva, desde o fabricante, o lojista, até o usuário, isto é, os agricultores. A legislação é bem clara e exigente sobre o descarte correto, porém, o controle, as vezes, é falho, ocorrendo o descarte incorreto o que pode possibilitar a ocorrência de intoxicação de seres humanos, contaminação corpos d'água e animais. Provavelmente, isto ocorra devido à falta de informações e de treinamentos, ou à insuficiência deles. Com isso, o objetivo desta pesquisa foi de diagnosticar o comportamento de um grupo de agricultores de São José dos Quatro Marcos (MT) com relação ao descarte correto das embalagens vazias de agrotóxicos, através de entrevistas semiestruturada e pesquisas bibliográficas. Observou-se que o grau de escolaridade do agricultor poderia ser um dos grandes fatores a interferir no grau de conhecimento dos agricultores sobre os agrotóxicos, fazendo com que essa falta de conhecimento prévio resultasse em ações entendidas como natural ao se trabalhar com os agrotóxicos.

Palavras-chave: ciências ambientais, defensivos agrícolas, legislação, psicologia ambiental. 


\section{INTRODUCTION}

Over the years, the use of pesticides has been intensified in order to control invasive plants, pests and diseases in crops, and to aid in increasing the quantity of crops per area. However, over time and with misuse, limitations to chemical control have emerged, such as the generation and disposal of empty pesticide packaging, which has negatively affected crop production processes and created risks for worker health and the environment.

Pesticides are defined by Brazilian Federal Laws ${ }^{\circ} .7,802$ from July $11^{\text {th }}$ of 1989 (Brasil, 1998) and $n^{\circ} .9,974$ from June $6^{\text {th }}$ of 2000 (Brasil, 2000), as products and agents of physical, chemical or biological processes for use in cultivation, storage and processing of agricultural products to alter the composition of the flora or fauna in order to preserve them from the action of harmful living things.

In order to alleviate pest infestations and, consequently, minimize losses in crop production, agriculture has been concerned with one of the results of chemical control, which is the generation and correct disposal of empty pesticide containers.

The final disposal of empty pesticide packaging is a procedure that requires the participation of all agents involved in the production chain, from manufacturing, marketing, use, supervision and monitoring of activities related to handling, transportation, storage and processing/reuse of this packaging.

Empty pesticide containers are often disposed of in inappropriate places and can become threatening to humans, animals and the environment when improperly disposed of.

Environmental contamination data due to incorrect disposal or even lack of knowledge about the consequences of misuse of empty pesticide packaging is of public concern due to the potential risk of air, soil and especially water contamination, directly interfering with quality of life and the environment (Luna et al., 1998).

Occupational exposure to pesticides is known to primarily affect farmers, who may be affected by direct handling (agricultural use) or through improper storage, reuse of packaging, contaminated clothing or water contamination (Rosa, 2017).

In Brazil, regulations were created that deal with the disposal of empty pesticide packaging under Federal Law No. 9,974 (Brasil, 2000). The National Institute for Container Processing, inpEV, established the concept of shared responsibility for the correct disposal of empty postconsumer pesticide packaging. These regulations attribute to farmers the task of returning the material to the merchants or distribution channels that, in turn, should return them to the manufacturers for their final destination. Likewise, supervisory institutions must verify the implementation of the NR 31 (Safety Regulatory Standard of Occupational Health in Agriculture, Livestock, Forestry, Forestry and Aquaculture) whose objective is to establish the precepts to be observed in the organization and in the work environment in order to make the planning and development of activities compatible with the safety and health of the work environment (BRASIL, 2005).

Brazil's reverse logistics initiative for post-consumer pesticide packaging is a world reference in this segment, with more than 414 receiving units for empty packaging present in all 25 states plus the Federal District (Inpev, 2015).

Shared responsibility throughout the reverse logistics chain is already a Brazilian reality. However, it is necessary to invest in changing the mindset of participants, especially with respect to the behavior of individuals, stimulating them to adopt attitudes that foster compliance with the legislation and thus ensure the end of problems arising from misuse or incorrect disposal of empty pesticide packaging.

Rev. Ambient. Água vol. 7 (supplement) - Taubaté 2019 
In terms of human psychology, it is difficult to describe the thought processes that drive our behavior, especially when our actions have become routine; however, learning new behavior can determine if and how changes in thought processes will occur (Tavares, 2005).

\section{MATERIALS AND METHODS}

The subject of this research was a group of farmers from the rural area of São José dos Quatro Marcos - Mato Grosso state (MT) along the MT-175 highway that employed chemical control techniques on their properties.

The municipality of São José dos Quatro Marcos, which had an estimated population of 18,452 inhabitants, is about $284 \mathrm{~m}$ in altitude and $303 \mathrm{~km}$ from the capital city of Cuiabá. Its territorial extension is about $1,281 \mathrm{~km}^{2}$ (IBGE, 2017) and is located in southwest Mato Grosso state. Its predominant relief is the Paraguay River depression and the Jauru River basin. The soil is pediplaned, weakly dissected, with tabular and convex forms. The climate is hot and subhumid tropical, with 4 months of drought, from June to September and annual precipitation of $1,500 \mathrm{~mm}$, with maximum intensity in December, January and February. The average annual temperature is $24^{\circ} \mathrm{C}$, with amplitude from $0^{\circ} \mathrm{C}$ to $42^{\circ} \mathrm{C}$ (MATO GROSSO, 2017).

The interviews were conducted at each farmer's house, where the project objective was explained, and the content of the questionnaire presented. Eighteen farmers were invited to participate in the research, of which 15 accepted the invitation, and all were over the age of 18 and they normally used pesticides on their properties. The interviewed farmers were considered research volunteers not receiving any kind of payment to participate in the research, as provided for in the previously signed consent form.

The questionnaire was applied during the 2017 agricultural year, following the approval of the Research Ethics Committee of the University of Taubaté, according to registration numbers 2.011.754 (CAAE number 63803316.6.0000.550). The questionnaire was composed of 19 questions: 7 about the farmer profile, 4 about pesticide legislation, 5 about personal protective equipment (PPE), 1 about storage and 1 about triple washing.

The set of criteria used to include farmers in the research was that they must be family farmers that use family labor on the property and that they use pesticides throughout all production periods.

Although the SOMA method (Albuquerque, 2008) provides for a systemic approach to complex issues through training, it also considers that the diagnosis of producers' knowledge and initial behaviors is necessary. Therefore, in this research, the applied methodology was an adaptation of the SOMA Method.

\section{RESULTS AND DISCUSSION}

For the 15 farms that were visited, $93 \%$ of pesticide applicators were the owners of the land on which they worked, while the remaining $7 \%$ of the applicators were family members; $73 \%$ of them were married and were between 19 and 71 years old. The level of education for $67 \%$ of the respondents was only elementary school ( $1^{\text {st }}$ to $5^{\text {th }}$ grade), which may represent a complicating factor in understanding the information contained on the labels and inserts that accompany pesticide packaging. Similar data were obtained by Vieira el al. (2006), where 65\% of interviewed farmers had a level of education of only elementary school.

Observing the level of education, it is difficult to imagine that these farmers would be able to read and interpret instructions and execute them properly. However, this situation becomes even more inadequate when, as opposed to receiving orientation from, official, qualified sources, the survey revealed that $80 \%$ of applicators received guidance on the preparation of pesticide solutions from retailers, or on calibration / adjustment of sprayers from other sources 
(46\%) such as family members and neighbors. When asked about specific training for correct application of pesticides, the group of farmers interviewed stated that they had not performed any training. The respondents who reported having high school and higher education was $13 \%$ for each level, or $26 \%$ of the total respondents. For this group of applicators, the interpretations of application techniques and execution of tasks is generally done with greater understanding and degree of assertiveness, although most of the technical information contained in package inserts and labels is not easily understood by these workers, according to Moro (2008).

Table 1 describes the profile of the pesticide applicators in this study and shows that $53 \%$ of pesticide applicators did not read the labels on product packaging, a result that is lower than that from Castelo-Branco (2003), who found that $12 \%$ of surveyed farmers in Nova Friburgo (RJ) had never read the labels. Furthermore, the $88 \%$ who said they read the labels only obtained the information through the pictures on the packaging. This creates risks for farmers by obtaining this information from unskilled sources of dubious origin.

Table 1. Pesticide applicator profile questions and response frequency (\%).

\begin{tabular}{lcc}
\hline & Yes (\%) & No (\%) \\
\hline Habit of reading pesticide packaging labels. & 47 & 53 \\
Knowledge of the meaning of the colored bands on the pesticide packaging labels. & 40 & 60 \\
Applicators that claim they use PPEs. & 47 & 53 \\
Habit of washing the PPE components. & 86 & 14 \\
Declared frequency of wearing gloves when washing PPE components. & 27 & 73 \\
Knowledge of triple washing. & 67 & 33 \\
Use of triple washing on the property. & 73 & 27 \\
Habit of puncturing empty pesticide containers. & 20 & 80
\end{tabular}

With respect to these pesticide applicators' knowledge of the meaning of the color strips on the pesticide packaging labels, $60 \%$ of respondents said they did not know their significance.

When the applicators were asked about the use of PPEs, only $47 \%$ answered that they use them following the procedures as described by Vieira et al. (2006) wherein for correct use the components must adequately cover the exposed parts of the body, which is the approach proposed by NR4 Rural Regulatory Standards for PPEs.

Incorrectly used pesticides can harm the health of the applicator and even family members who do not apply them; however, 53\% of these respondents do not use PPEs. When asked why PPEs are not used the farmers justified the lack of use of PPE due to the financial cost and simply because they do not want to make use of them. Another important issue is the fact that the climate of the region is very hot, and the protective equipment is uncomfortable due to the material it is made from.

For PPE items to be able to offer worker protection they must be washed after each application. The pesticide applicators habit of washing the PPE components show that $86 \%$ of them wash PPEs, $67 \%$ wash after each application, and 62\% of the PPEs are washed by each applicator himself.

Of the applicators, $73 \%$ do not wear gloves while washing the PPE components, however $20 \%$ use gloves. According to Soares et al. (2005), environmental education is essential for reducing harm to a farmer's health, as it is related to the hygiene and washing aspects of PPEs, and which plays an important role in the probability of poisoning; in general, a lack of environmental education increase chances of poisoning.

Thus, Santos (2010) reported that it is up to environmental education to lead people to understand the close interaction between a balanced environment and human quality of life, besides showing that environmental education is not limited to the preservation of the environment, but also incorporates social, economic, ethical and political aspects. It is essential 
that environmental education leads to the practice of reflection, building the concept of autonomy and broadening the idea of citizenship. For these reasons, the environmental issue still finds resistance in some countries and some segments of society, as its objectives go beyond basic environmental aspects.

It was also found that $67 \%$ of participants know what the triple washing is and $73 \%$ practice it on their property. According to inpEV (1998), the procedure of triple washing follows the determinations of ABNT NBR 13.968 (Brazilian Technical Standard), which was published in 1997 and guides the procedure of washing empty pesticide packages in the field, according to accepted standards adopted worldwide. This standard defines that empty rigid packaging, when subjected to proper internal washing procedures should have a waste content of less than 100 ppm (parts per million) and become a non-hazardous waste.

Reinato et al. (2012) states that in the triple package washing process the residual waste is reduced to approximately the following concentrations: $1.2 \%$ in the first wash, $0.0144 \%$ in the second wash and $0.0001728 \%$ in the third wash. Thus, when pesticide packaging is processed after triple washing, contamination risks are virtually negligible, and it can be classified as nonhazardous waste.

For Brazilian legislation, Art. 6, § 2 and 4 (Law 7.802 / 1989) triple-washed empty pesticide packaging must be perforated and stored with their labels intact, thus facilitating their identification. Contaminated non-washable packaging should be stored in a retailer's supplied plastic bag which it should be properly sealed (Lei 7.802/1989; Art. $6^{\circ}$, § $2^{\circ}$ e $4^{\circ}$ ).

Finally, $80 \%$ of respondents informed that they do not puncture the packaging for disposal, as is required by law to make the containers unusable so that contamination does not occur through alternative usage.

\section{CONCLUSIONS}

Under the conditions of this research, knowledge about the correct and safe use of pesticides was shown to be heavily influenced by the level of literacy, and this factor is, in fact, the major influence on the adoption of behaviors for the correct disposal of pesticide packaging.

It is noteworthy that the farmers surveyed only comply with certain "pro-environmental attitudes" when required by law, for which non-compliance can result in a fine, regardless of consideration for their health or the environment.

\section{REFERENCES}

ALBUQUERQUE, C. Método Soma: capitação de agricultores, educação sanitária e ambiental. Goiânia: Bandeirante. 2000. 240p.

BRASIL. IBGE. Censo Demográfico. 2017. Available at: http://www.ibge.gov.br

BRASIL. Lei $\mathrm{n}^{\circ}$ 7.802, de 11 de julho de 1989. Dispõe sobre a pesquisa, a produção, a embalagem e rotulagem, o transporte, o armazenamento, a comercialização, a propaganda comercial, a utilização, a importação, a exportação, o destino final dos resíduos e embalagens, o registro, a classificação, o controle, a inspeção e a fiscalização de agrotóxicos, seus componentes e afins, e dá outras providências. In: Legislação federal de agrotóxicos e afins. Brasília (DF): Ministério da Agricultura e do Abastecimento; 1998. p. 7-13.

BRASIL. MINISTÉRIO DO TRABALHO E EMPREGO. NR 31 - Segurança e Saúde no Trabalho na Agricultura, Pecuária, Silvicultura, Exploração Florestal e Aquicultura. 2019.

Available at: 
http://portal.mte.gov.br/data/files/8A7C812D2E7318C8012F53EC9BF67FC5/NR-31 (atualizada).pdf

CASTELO-BRANCO, M. Avaliação do conhecimento do rótulo dos inseticidas por agricultores em uma área agrícola do Distrito Federal. Horticultura Brasileira, p. 570$573,2003$.

INPEV. Instituto Nacional de Processamento de Embalagens de Agrotóxicos Vazias. 1998. Available at: http://www.inpev.org.br/

INPEV. Instituto Nacional de Processamento de Embalagens de Agrotóxicos Vazias. 2015. Available at: http://www.inpev.org.br/

LUNA A. J.; SILVA L. T.; SALES R. F. et al. Agrotóxicos: "Responsabilidade de Todos" (Uma abordagem da questão dentro do paradigma do desenvolvimento sustentável). Pernambuco, PE. Tese de Mestrado, UFP. p. 3 - 17. 1998.

MATO GROSSO. Geografia de São José dos Quatro Marcos. 2017. Available at: http://www.portalmatogrosso.com.br.

MORO, B. P. Um estudo sobre a utilização de agrotóxicos e seus riscos na produção do fumo no município de Jacinto Machado/SC. Monografia (Especialização) Universidade do Extremo Sul Catarinense - UNESC. Criciúma. 2008.

REINATO, R. A. O.; GARCIA, R. B. G.; ZERBINATTI, O. E. A situação atual das embalagens vazias de agrotóxicos no Brasil. Engenharia Ambiental - Espírito Santo do Pinhal, v. 9, n. 4, p. 79-94, 2012.

RICHARDSON, R. J. Y. et al. Pesquisa social: métodos e técnicas. 3. ed. São Paulo: Atlas, 2011. $334 \mathrm{p}$.

ROSA, A. R. Manejo e descarte de resíduos de embalagens de agrotóxicos em um município da Serra Gaúcha. Dissertação (Mestrado), Universidade de Caxias do Sul, Programa de Pós-Graduação em Engenharia e Ciências Ambientais, 2017.

SANTOS, C. A. Armazenamento de embalagens de agrotóxicos utilizados na atividade agrícola em catalão (GO) e seus impactos ambientais. - Anápolis: Centro Universitário de Anápolis - Uni Evangélica. 2010. 157 p. il.

SOARES, W. L.; FREITAS, E. A.; COUTINHO, J. A. Trabalho rural e saúde: intoxicações por agrotóxicos no município de Teresópolis - RJ. Revista de Economia e Sociologia Rural, v. 43, n. 4, p. 685-701, 2005.

TAVARES, L. Abordagem cognitivo - Comportamental no atendimento de pacientes com história de depressão e déficit em habilidades sociais. Graduação, Universidade Federal de Santa Catarina centro de filosofia e ciências humanas. 2005. http://newpsi.bvspsi.org.br/tcc/83.pdf

VIEIRA, E. M.; NITZSCHE, T.; MASCARETTE, A. O grau de conhecimento do trabalhador rural sobre defensivos agrícolas na região do Alto Tietê - SP antes e após. XLIV Congresso da SOBER. Fortaleza, CE, Brasil. 2006. 